\title{
In vitro performances of a valved holding chamber with inhaled corticosteroids
}

\author{
Nabile Boukhettala*, Thierry Porée, Lissbeth Leon-Bollotte \\ From 3rd WAO International Scientific Conference (WISC) 2014 \\ Rio de Janeiro, Brazil. 6-9 December 2014
}

\section{Background}

In young children with asthma, it is recommended to use pressurised metered dose inhaler (PMDI) with a valved holding chamber (VHC). The objective of this study was to evaluate the performances of a VHC with inhaled corticosteroids.

\section{Methods}

In this study, the VHC called Tipshaler (Protec'som, France) was evaluated with fluticasone (Flixotide ${ }^{\circledR}$, $50 \mu \mathrm{g} / \mathrm{dose}, \mathrm{GSK}$, France) and beclomethasone $\left(\mathrm{QVAR}^{\circledR}\right.$, $100 \mu \mathrm{g} /$ dose, MEDICIS, Canada). The method according to the European Pharmacopoeia used a constant flow rate $(30 \mathrm{~L} / \mathrm{min})$ was used. Particle size distribution was measured using a NGI cascade impactor (Copley Scientific, Nottingham, United Kingdom). The fluticasone and beclomethasone concentrations were assayed by spectrophotometry at $236 \mathrm{~nm}$ and $239 \mathrm{~nm}$ respectively.

\section{Results}

In the trachea, the mass of fluticasone was higher with pMDI alone in comparison with VHC $(20 \pm 0,6 \mu \mathrm{g}$ vs 0,9 $\pm 0,3 \mu \mathrm{g}, \mathrm{p}<0,05)$. The fine particle dose of fluticasone was similar with pMDI alone compared to VHC (26 \pm 2 $\mu \mathrm{g}$ vs $24 \pm 1 \mu \mathrm{g})$. Concerning beclomethasone, in the trachea the mass of drugs was higher with pMDI alone in comparison with $\mathrm{VHC}(11,6 \pm 0,4$ vs $1,2 \pm 0,2, \mathrm{p}<0.05)$. In addition, deposition of fine particles of beclomethasone was similar with pMDI alone in comparison with VHC (77 $\pm 1 \mu \mathrm{g}$ vs $75 \pm 1 \mu \mathrm{g}, \mathrm{p}<0.05$ ).

\section{Conclusions}

The use of valved holding chamber reduces the deposition of particles of inhaled corticosteroids in the trachea and allows efficient lung deposition of drugs.
Published: 8 April 2015

doi:10.1186/1939-4551-8-S1-A195

Cite this article as: Boukhettala et al:: In vitro performances of a valved holding chamber with inhaled corticosteroids. World Allergy Organization Journal 2015 8(Suppl 1):A195.
Submit your next manuscript to BioMed Central and take full advantage of:

- Convenient online submission

- Thorough peer review

- No space constraints or color figure charges

- Immediate publication on acceptance

- Inclusion in PubMed, CAS, Scopus and Google Scholar

- Research which is freely available for redistribution

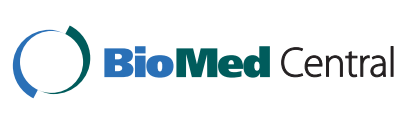

